\title{
Consumption of anthelmintic fox baits by target and non-target mammals in Japan
}

\author{
Yuna Sakurai, Kohji Uraguchi, Hirokazu Kouguchi \& Tatsuo Oshida*
}

ABSTRACT. Echinococcosis is a zoonosis caused by the tapeworm Echinococcus multilocularis, which uses red fox (Vulpes vulpes) as a principle definitive host. To decrease E. multilocularis prevalence in red foxes, feeding the "fox bait" containing anthelmintic praziquantel to red foxes is effective. However, a previous investigation conducted in Hokkaido, Japan showed that raccoon dogs (Nyctereutes viverrinus albus), raccoons (Procyon lotor), domestic cats (Felis catus), and murids frequently consumed fox baits without the anthelmintic praziquantel, suggesting they compete with red foxes for the bait. On the other hand, anthelmintic praziquantel has a bitter taste and unpleasant odor to dogs (Canis lupus familiaris) and cats. The inclusion of anthelmintic praziquantel in the bait may deter the consumption of fox baits by nontarget mammals. Therefore, by using camera traps, we examined the seasonal consumption of fox baits with the anthelmintic praziquantel by mammals in Memuro, Tokachi District, Hokkaido, Japan, from May to October, 2019. We found that red foxes, raccoons, raccoon dogs, murids, and Eurasian red squirrels (Sciurus vulgaris) frequently consumed fox baits. Therefore, the bitterness and smell of the bait do not efficiently work to prevent consumption by non-target mammals. Of those, raccoon dogs were most frequent consumers of the fox bait. Raccoons and Eurasian red squirrels also frequently consumed the fox bait, especially in spring and in autumn, respectively. These results show competition for fox baits by non-target mammals. This should be considered for planning of the baiting campaign.

How to cite this article: Sakurai Y., Uraguchi K., Kouguchi H., Oshida T. 2021. Consumption of anthelmintic fox baits by target and non-target mammals in Japan // Russian J. Theriol. Vol.20. No.2. P.183-187. doi: 10.15298/rusjtheriol.20.2.07

KEY WORDS: anthelmintic praziquantel, echinococcosis, red fox, Vulpes vulpes.

YunaSakurai[yuu70a@gmail.com] \& Tatsuo Oshida [oshidata@obihiro.ac.jp],Laboratoryof Wildlife Biology, Obihiro University of Agriculture and Veterinary Medicine, Inada, Obihiro 080-8555, Japan; Kohji Uraguchi [ura@iph.pref. hokkaido.jp] \& Hirokazu Kouguchi [kouguchi@iph.pref.hokkaido.jp], Department of Infectious Disease, Hokkaido Institute of Public Health, Sapporo 060-0819, Japan.

\section{Поедание антигельминтных приманок для лисиц целевыми и нецелевыми млекопитающими в Японии}

\author{
Ю. Сакураи, К. Урагучи, Х. Когучи, Т. Ошида*
}

РЕЗЮМЕ. Эхинококкоз - это зооноз, вызываемый ленточным червем Echinococcus multilocularis, при этом в качестве основного хозяина выступает лисица Vulpes vulpes. Для снижения распространенности E. multilocularis, применяют специальную «приманку для лисиц», содержащую антигельминтный празиквантел. Однако предыдущее исследование, проведенное на Хоккайдо, Япония, показало, что енотовидные собаки (Nyctereutes viverrinus albus), еноты (Procyon lotor), домашние кошки (Felis catus) и мышевидные грызуны часто употребляли приманки для лисиц без празиквантела, что позволяет предположить, что они могут конкурировать с лисицами. С другой стороны, антигельминтный празиквантел имеет горький вкус и неприятный запах для собак и кошек. Включение в приманку празиквантела может сдерживать потребление приманок для лисиц нецелевыми млекопитающими. Поэтому с помощью фотоловушек мы исследовали сезонное потребление приманок для лисиц с празиквантелом млекопитающими в Мемуро, район Токачи, Хоккайдо, Япония, с мая по октябрь 2019 г. Мы обнаружили, что лисицы, еноты, енотовидные собаки, мышевидные грызуны и обыкновенные белки (Sciurus vulgaris) часто употребляли в пищу приманки для лисиц. Следовательно, горечь и запах приманки не действуют эффективно, чтобы предотвратить её потребление нецелевыми млекопитающими. Наиболее частыми потребителями приманки были енотовидные собаки. Еноты 
и белки также часто поедали приманку, особенно весной и осенью соответственно. Эти результаты свидетельствуют о конкуренции за приманки для лисиц со стороны нецелевых млекопитающих, что следует учитывать при планировании кампании по дегельминтизации.

КЛЮЧЕВЫЕ СЛОВА: антигельминтный празиквантел, эхинококкоз, лисица, Vulpes vulpes.

\section{Introduction}

Echinococcosis is a serious zoonotic disease caused by the metacestode stage of Echinococcus multilocularis, which is parasitic to human organs, especially the liver and kidney (Yamashita \& Kamiya, 1997). This parasitosis is widespread in the Northern Hemisphere (Soulsbury et al., 2010). In Hokkaido, Japan, the life cycle of E. multilocularis relies on the red fox (Vulpes vulpes) as the main definitive host with the main intermediate host of murids, such as the gray red-backed vole (Craseomys rufocanus) (Tsukada, 2005). Humans are also intermediate hosts after oral ingestion of E. multilocularis eggs shed by red foxes (e.g. Yokohata, 2015). Each year, 15-20 people are newly diagnosed with echinococcosis (e.g. Hokkaido Government, Japan, http://www.pref.hokkaido.lg.jp/hf/kst/kak/0000contents/ ekino/index.htm). The infection rate of red foxes in Hokkaido is estimated at $40 \%$ (Nonaka, 2014). Thus, it is important to prevent from E. multilocularis infection in red foxes.

A fox bait with anthelmintic praziquantel has been identified as an effective strategy to decrease the prevalence of E. multilocularis in red foxes (Takahashi et al., 2002; Hegglin et al., 2003; Romig et al., 2007; König et al., 2019). In fact, in Hokkaido, the baiting campaign has been successful in reducing the infection rate of E. multilocularis in red foxes (Tsukada, 2005). However, long-term baiting is necessary to maintain a low infection rate (Hokkaido Government, 2007).

In the agricultural area of eastern Hokkaido, Takyu et al. (2013) reported that fox baits without anthelmintic praziquantel are often consumed by non-target mammals, such as domestic dogs (Canis lupus familiaris) and cats (Felis catus). Recently, in the riparian forest of the agricultural area of eastern Hokkaido, Arisawa et al. (2020) also experimentally demonstrated that raccoon dogs (Nyctereutes viverrinus albus), raccoons (Procyon lotor), domestic cats, and murids consumed fox baits that did not contain anthelmintic praziquantel. Therefore, these species may compete with red foxes for the bait. If they frequently consume fox baits, the red fox baiting campaign may not be effective. Bernachon et al. (2014), however, reported that the anthelmintic praziquantel has a bitter taste and an unpleasant odor to dogs (Canis lupus) and cats (Felis catus). The bitterness and smell of the bait are expected to reduce bait consumption by non-target mammals. In the present study, we examined the effect of anthelmintic praziquantel on bait consumption by wild mammals in agricultural areas in eastern Hokkaido. The experiment was conducted in Memuro, Tokachi District, Hokkaido, where Arisawa et al. (2020) had previously undertaken similar experiments using baits without anthelmintic praziquantel. We compare our results with Arisawa et al. (2020).

\section{Material and methods}

\section{Study area}

This study was conducted in the agricultural area of Memuro, Tokachi District in eastern Hokkaido, Japan $\left(42.88^{\circ} \mathrm{N}, 142.98^{\circ} \mathrm{E}\right.$, see Fig. 1), as described in Arisawa et al. (2020). The average temperature and precipitation are $6.1^{\circ} \mathrm{C}$ and $957.3 \mathrm{~mm}$, respectively (Japan Meteorological Agency, http://www.jma.go.Jp/jma/menu/report.html). Arisawa et al. (2020) reported on many mammal species, the potential non-target, here. We targeted our investigation in riparian forests along the Shibu-san River. Following Takyu et al. (2013), a transect line of approximately $5.0 \mathrm{~km}$ was established along the Shibu-san River. Ten study sites were established at approximately $500 \mathrm{~m}$ intervals (Fig. 1).

\section{Baiting and camera trapping}

The bait was created following the methodology of Takahashi et al. (2010). The bait ingredients included:

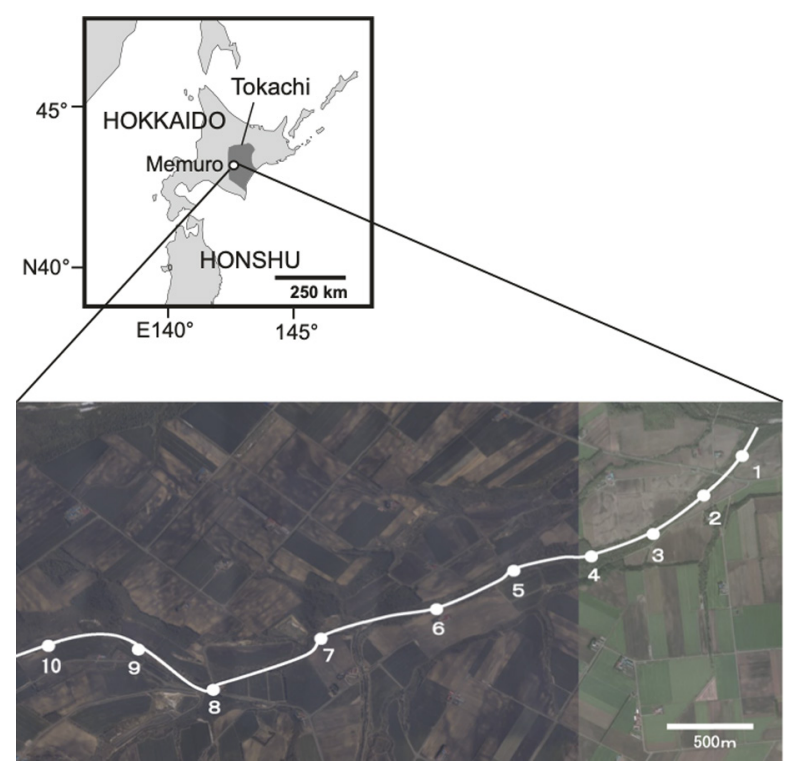

Fig. 1. Study area in Memuro, Tokachi District, Hokkaido, Japan. This is a modified figure previously published by Arisawa et al. (2020). The numbered white circles indicate the location of the study sites. The white line indicates the Shibusan River. The map is based on an aerial photograph published by Geospatial Information Authority of Japan. 
palm oil, sunflower oil, and fish meal, and anthelmintic praziquantel. The weight of each bait was approximately $15 \mathrm{~g}(44 \times 44 \times 15 \mathrm{~mm})$.

According to Takyu et al. (2013), at each study site, we placed five baits on a wooden board $(450 \times 300 \times 2.5 \mathrm{~mm})$ on the ground. We set a camera trap (FieldnoteDS6010, Marifu Co. Ltd., Japan) approximately $3 \mathrm{~m}$ from the board. The camera trap was fixed on the trunk or bough of a tree at approximately $150-170 \mathrm{~cm}$ in height. The study period was from May to October, 2019. Each month, we surveyed the fox baits and camera traps for seven continuous days with an interval of two to three weeks between each survey. During the survey period, we monitored the camera trap and daily bait consumption and replaced any consumed bait with fresh bait.

\section{Data analyses}

Following Arisawa et al. (2020), we divided the data into three seasons: spring (May and June), summer (July and August), and autumn (September and October). We compared seasonal variations using a Chi-squared test.

We counted the number of photographs of each mammal species captured by the camera traps. It was difficult to identify each individual, therefore we followed the methodology of Zlatanova \& Popova (2018) to avoid counting multiple photographs of the same individual as possible. We did not include any subsequent photographs made within $20 \mathrm{~min}$ of an initial photograph, unless it was of a different species. When more than one individual was photographed at the same time within $20 \mathrm{~min}$, the maximum number of individuals taken in any one photograph was recorded, following Iwashita et al. (2015). In addition, we calculated the disappearance rates of baits each season. We counted the number of missing baits at each study site and then calculated the disappearance rate as follows:

bate disappearance rate $=$ the total number of bates that disappeared for each season / the total number of bates placed for each season (50 baits $\times 7$ days $\times$ 2 months $=700$ baits $) \times 100 \%$.

Following Ishida et al. (2014), we determined whether photographed species were baits consumers by analyzing the sequence photographs of each individual. When the number of bait had decreased after the mammal left the study site, we regarded the individual as a consumer and counted these cases as "estimated consumption". In addition, when the camera trap captured the mammal eating the bait, we counted these cases as "certain consumption". To analyze the reliability of "the estimated consumption", we compared "estimated consumption" with "certain consumption" using a Chi-squared test.

\section{Results}

In a total of 42 trapping days, the camera traps comprised 97 photos of red foxes, 88 raccoons (Procyon lotor), 326 raccoon dogs (Nyctereutes viverrinus albus), 75 murids, 237 Eurasian red squirrels (Sciurus vulgaris orientis), 11 weasels, 14 birds, 11 domestic cats, four sika deer (Cervus nippon yesoensis), three brown bears (Ursus arctos), three bats, one Siberian flying squirrel (Pteromys volans orii), and six unidentified mammals. It was difficult to identify the species of murids, weasels, birds, and bats. Based on the number of photos, we categorized animals into six main groups: red foxes, raccoons, raccoon dogs, murids, Eurasian red squirrels, and others.

Raccoons, raccoon dogs, and Eurasian red squirrels were photographed at every study site. Red foxes and murids were photographed at nine sites. The proportions of animal species photographed were significantly different between spring and summer $\left(\chi^{2}\right.$-test, $\left.p<0.001\right)$ and between summer and autumn $\left(\chi^{2}\right.$-test, $\left.p<0.001\right)$ (Fig. 2). Red foxes were more frequently photographed in autumn $(n=44)$, which was twice as many as in summer $(n=$ $22)$. The number of photographed raccoons decreased from spring $(n=39)$ to autumn $(n=18)$. The frequency of photographed raccoon dogs increased four times from spring ( $n=39)$ to summer $(n=149)$, and decreased slightly in autumn $(n=138)$. The number of murids photographed in spring $(n=33)$ was similar to that in autumn $(n=29)$, but murid numbers in summer were lower $(n=13)$. The frequency of Eurasian red squirrels photographed in spring $(n=68)$ was similar to summer $(n=68)$, but radically increased in autumn $(n=100)$.

The estimated consumption by red foxes was 25 , raccoons was 27 , raccoon dogs was 85 , murids was 26 , Eurasian red squirrels was 101, and others was 9. The certain consumption of bait by red foxes was 11, raccoons was 12 , raccoon dogs was 42 , murids was 13 , Eurasian red squirrels was 29 , and others was 9 . The estimated consumption was not significantly different from the certain consumption $\left(\chi^{2}\right.$-test, $\left.p>0.05\right)$. Therefore, we considered both consumptions revealing similar in trends and will collectively use the term "the bait consumption" in our findings (Fig. 3).

The bait disappearance rate was $70.1 \%$ in total. Seasonal disappearance rates were $55.1 \%$ in spring, $87.4 \%$ in summer, and $67.6 \%$ in autumn (Fig. 3 ). The proportions of the bait consumed by mammals were significantly different between spring and summer

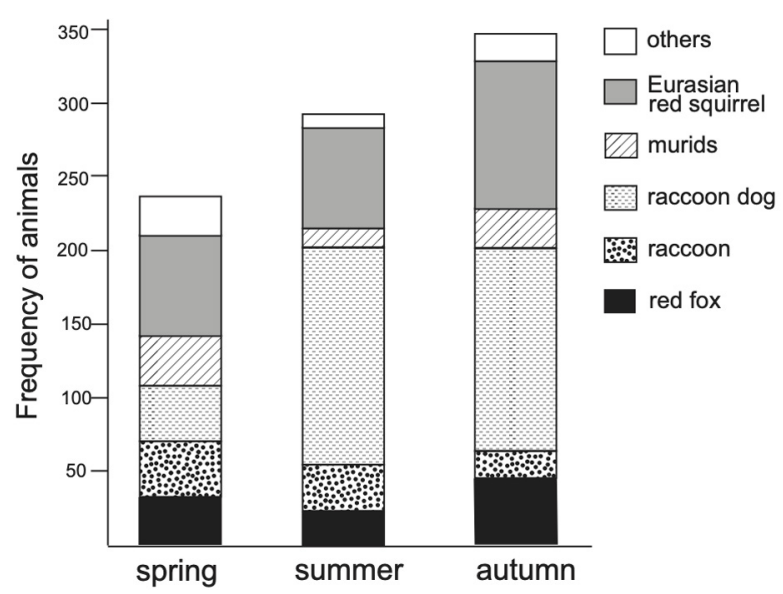

Fig. 2. Seasonal change in animals photographed by the camera-traps from May to October, 2019 in Memuro, Tokachi District, Hokkaido, Japan. 


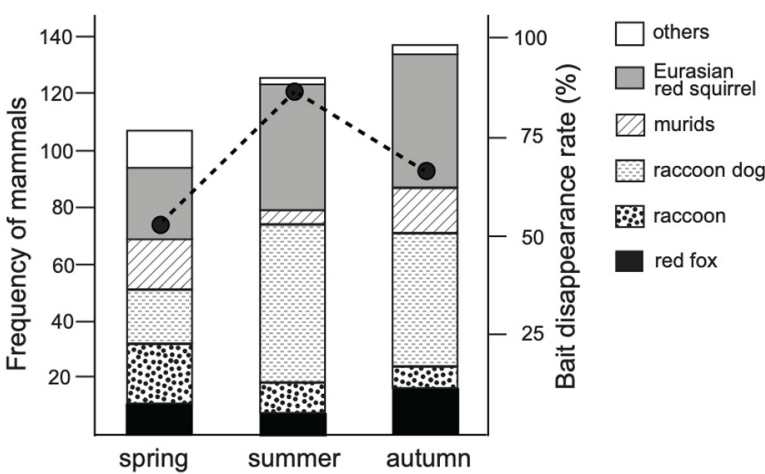

Fig. 3. Seasonal change in mammals detected as fox bait consumers from May to October, 2019 in Memuro, Tokachi District, Hokkaido, Japan. The dotted line provides the seasonal change in bait disappearance rate (\%).

$\left(\chi^{2}\right.$-test, $\left.p<0.001\right)$. There was no significant difference in bait consumption by mammals between summer and autumn $\left(\chi^{2}\right.$-test, $\left.p>0.05\right)$. The bait consumption by red foxes was lower than other species ( $n=11$ in spring, $n=$ 8 in summer, and $n=17$ in autumn). In the total of bait consumption by all mammals, the bait consumption by red foxes was $1.7 \%$. The bait consumption by raccoons decreased from spring to autumn, with raccoons most frequently consuming baits in spring ( $n=21)$ (Fig. 3). Raccoon dogs showed higher bait consumption than other species ( $n=19$ in spring, $n=55$ in summer, and $n=$ 47 in autumn). Murids showed lower bait consumption than all other species ( $n=18$ in spring, $n=5$ in summer, and $n=16$ in autumn). Eurasian red squirrels were the second highest bait consumers $(n=25$ in spring, $n=44$ in summer, and $n=47$ in autumn).

\section{Discussion}

We identified that the fox bait containing anthelmintic praziquantel were mainly consumed by red foxes, raccoon dogs, raccoons, murids, and Eurasian red squirrels in the agricultural area of eastern Hokkaido. Arisawa et al. (2020) reported that the fox bait without the anthelmintic praziquantel was consumed by red foxes, raccoon dogs, raccoons, and murids were a bait consumer. Interestingly, despite the addition of the anthelmintic praziquantel, we detected one additional bait consumer, Eurasian red squirrel. Although Bernachon et al. (2014) reported that anthelmintic praziquantel has a bitter taste and foul odors to dogs and cats, it is doubtful that it is offensive to many mammalian species. The results show the anthelmintic praziquantel does not reduce bait consumption by nontargets. If baiting of red foxes is to be practical, this consumption needs to be reduced or eliminated.

The total bait consumption by raccoon dogs, raccoons, murids, and Eurasian red squirrels was higher than red foxes. A protoscolex of $E$. multilocularis parasitizes the small intestinal mucosa of raccoon dogs, but does not reach complete maturity in Hokkaido (Oku, 2010). In Europe, however, Schwarz et al. (2011) reported that raccoon dogs introduced from East Asia were a definitive host for E. multilocularis. Therefore, baiting raccoon dogs may effectively prevent echinococcosis from spreading. The introduced raccoons in Hokkaido (Ikeda, 2015), are not principle definitive host of E. multilocularis (Asakawa et al., 2000). However, Arisawa et al. (2020) suggested that competition for the baits by raccoons reduce the volume of baits available for red foxes. In this case, the baiting campaign may not be effective in preventing echinococcosis in the red fox populations of Hokkaido. For an effective baiting campaign, we need to decrease the bait consumption by raccoons. Our results suggest the frequency of raccoons consumption decreased from spring to summer. In the agricultural area of Hokkaido, raccoons are thought to consume more nutritious feedstuff in spring with more natural resources available (such as fruits and nuts) in summer and autumn (Yamaguchi, 2015). Therefore, raccoons might appear more frequently into agricultural areas in spring than in summer and autumn. Eurasian red squirrels appeared at all survey sites, and their bait consumption increased from spring to summer. Additionally, Eurasian red squirrel behavior may reduce opportunities for red foxes to consume fox baits. Similarly, murid bait consumption may impact bait availability for red foxes.

In the total of bait consumption by all mammals, the bait consumption by red foxes was $1.7 \%$. In a previous study in Koshimizu Town, Hokkaido, the percentage of baits consumed by red foxes was $38.3 \%$ when the fox baits were placed around red fox dens for one year (Tsukada et al., 2002). Although it is difficult to directly compare with these results because of the different experimental conditions, the fox bait consumption detected in the present study is low. To increase the consumption of fox baits by red foxes, the impact of non-target mammals needs to be decreased.

Fox bait disappearance rates differed between seasons, with a relatively higher rate in summer $(87.4 \%)$. The total number of mammals that consumed the fox baits, however, was higher in autumn than that in summer. In autumn, the highest fox bait consumption by red foxes was observed, but also by Eurasian red squirrels. In the present study, the fox bait consumption by Eurasian red squirrels was much higher than the consumption by red foxes. Eurasian red squirrels frequently store food underground during autumn, such as nuts and corn (Gurnell, 1987). The increase in the number of fox bait consumption by Eurasian red squirrels in autumn may be related to their food hoarding behavior. Therefore, in autumn, Eurasian red squirrels may prevent red foxes from obtaining the fox baits in Hokkaido by competition. When we conduct a red fox baiting campaign to red foxes, it may be necessary to consider consumption for the baits by Eurasian red squirrels in autumn and raccoons in spring.

\section{Conclusion}

In the present study, fox baits with the anthelmintic praziquantel were mainly consumed by red foxes, 
raccoon dogs, raccoons, murids, and Eurasian red squirrels in the agricultural area of eastern Hokkaido. Raccoon dog, which is thought to be one of principle definitive hosts of E. multilocularis, consumed the fox baits more frequently than other species. Raccoons and Eurasian red squirrels also frequently consumed the fox baits in spring and autumn, respectively. These species may compete with red foxes for the bait. Therefore, for efficient red fox baiting campaigns in the future, we must manage bait consumption by non-target mammals.

ACKNOWLEDGEMENTS. We thank E. Yamaguchi (Hokkaido Research Organization) and Y. Asari and T. Akasaka (Obihiro University of Agriculture and Veterinary Medicine) for their helpful information and comments on this study. We thank K. Kawamura, M. Kumagai, and H. Kikuchi for their technical assistance.

\section{References}

Arisawa H., Uraguchi K., Kouguchi H. \& Oshida T. 2020. Note on consumption of fox bait by alien raccoons in eastern Hokkaido, Japan // Russian Journal of Theriology. Vol.19. P.178-182.

Asakawa M., Matoba Y., Yamada D. \& Kamiyama T. 2000. Review of the parasitological state of feral raccoons captured in Nopporo National Park and its proximity, Hokkaido // Journal of Rakuno Gakuen University. Vol.25. P.1-8 [in Japanese with English summary].

Bernachon N., McGahie D., Corvaisier D., Benizeau E., Crastes N. \& Chaix G. 2014. Comparative palatability of two veterinary dewormers (Milpro ${ }^{\circledR}$ and Milbemax ${ }^{\circledR}$ ): A blinded randomised crossover cat study // Veterinary Record Open. Vol.1. P.e000080.

Gurnell J. 1987. The Natural History of Squirrels. London: Christopher Helm. 201 p.

Hegglin D., Ward P.I. \& Deplazes P. 2003. Anthelmintic baiting of foxes against urban contamination with Echinococcus multilocularis // Emerging Infection Diseases. Vol.9. P.1266-1272.

Hokkaido Government. 2007. [A Guideline Using Anthelmintics on Red Foxes: Measures against Echinococcosis]. Sapporo: Hokkaido Government. 15 p. [in Japanese].

Ikeda T. 2015. Procyon lotor (Linnaeus, 1758) // Ohdachi S.D., Iwasa M.A., Ishibashi Y., Fukui D. \& Saitoh T. (eds.). The Wild Mammals of Japan. 2nd ed. Kyoto: Shoukadoh Book Seller. P.232-233.

Ishida A., Takahashi K., Uraguchi K. \& Oshida T. 2014. Environmental factors for efficiently baiting red foxes in agricultural areas in eastern Hokkaido, Japan // Mammal Study. Vol.39. P.167-172.

Iwashita A., Ogawa H. \& Ando M. 2015. Effectiveness of camera trap data as relative abundance index of the raccoon (Procyon lotor) // Journal of Agricultural Science, Tokyo University of Agriculture. Vol.60. P.69-76 [in Japanese with English summary].

König A., Romig T. \& Holzhofer E. 2019. Effective longterm control of Echinococcus multilocularis in a mixed rural-urban area in southern Germany // PLOS ONE. Vol.14. No.4. P.e0214993.

Nonaka N. 2014. [Echinococcosis and countermeasure for its infectious source] // Journal of Veterinary Epidemiology. Vol.18. P.150-152 [in Japanese].

Oku Y. 2010. [Echinococcosis]. Tokyo: Japan Livestock Industry Association. 19 p. [in Japanese].

Romig T., Bilger B., Dinkel A., Merli M., Thoma D., Will R., Mackenstedt U. \& Lucius R. 2007. Impact of praziquantel baiting on intestinal helminths of foxes in southwestern Germany // Helminthologia. Vol.44. P.137-144.

Schwarz S., Sutor A., Staubach C., Mattis R., Tackmann K. \& Conraths F.J. 2011. Estimated prevalence of Echinococcus multilocularis in raccoon dogs Nyctereutes procyonoides in northern Brandenburg, Germany // Current Zoology. Vol.57. P.655-661.

Soulsbury C.D., Baker P.J., Iossa G. \& Harris S. 2010. Red foxes (Vulpes vulpes) // Gehrt S.D., Riley S.P.D. \& Cypher B.L. (eds.). Urban Carnivores: Ecology, Conflict, and Conservation. Baltimore: Johns Hopkins University Press. P.62-75.

Takahashi K., Uraguchi K., Romig T., Hatakeyama H. \& Tamura M. 2002. [Preliminary report on Echinococcus multilocularis control by fox bating with paraziquantel] // Report of the Hokkaido Institute of Public Health. Vol.52. P.61-63 [in Japanese].

Takahashi K., Uraguchi K., Abe S. \& Hirakawa, H. 2010. [Making acceptable bait by red foxes] // Report of the Hokkaido Institute of Public Health. Vol.60. P.81-82 [in Japanese].

Takyu M., Takahashi K., Uraguchi K. \& Oshida T. 2013. Fox bait consumption and camera trapping in agricultural areas in eastern Hokkaido, Japan // Mammal Study. Vol.38. P.57-60.

Tsukada H., Hamazaki K., Ganzorig S., Iwaki T., Konno K., Lagapa J.T., Matsuo K., Ono A., Shimizu M., Sakai H., Morishima Y., Nonaka N., Oku Y. \& Kamiya M. 2002. Potential remedy against Echinococcus multilocularis in wild red foxes using baits with anthelmintic distributed around fox breeding dens in Hokkaido, Japan // Parasitology. Vol.125. P.119-129.

Tsukada H. 2005. [Foraging behavior of red foxes and echinococcosis] // Honyurui Kagaku [Mammalian Science]. Vol.45. P.91-98 [in Japanese].

Yamaguchi E. 2015. [Environmental Risk Factors Associated with Infection in Raccoons]. PhD Thesis. Morioka: The United Graduate School of Agricultural Sciences, Iwate University. 105 p. [in Japanese with English summary].

Yamashita J. \& Kamiya M. 1997. [Echinococcus: Its Characters and Preventives]. Sapporo: Hokkaido University Press. 274 p. [in Japanese].

Yokohata Y. 2015. Wild mammal-borne zoonoses and mammalogists in Japan // Ohdachi S.D., Iwasa M.A., Ishibashi Y., Fukui D. \& Saitoh T. (eds.). The Wild Mammals of Japan. 2nd ed. Kyoto: Shoukadoh Book Seller. P.228-231.

Zlatanova D.P. \& Popova E.D. 2018. Biodiversity estimates from different camera trap surveys: a case study from Osogovo MT., Bulgaria // Nature Conservation Research. Vol.3. P.13-25. 